\title{
The double agent: aspects of literary translator affect as revealed in fictional work by translators
}

\author{
Jean Anderson \\ Victoria University of Wellington
}

How do translator-authors represent translators and the translation act in fiction? What do such works indicate about the affective aspects of translation and literary translation in particular? This introductory survey of these issues analyses several fictional works written by translators, to show that certain emotional responses recur, and that while there is little research into affect and literary translation, there are elements commonly found in studies of bilingualism which are echoed in the works of fiction studied. Whether these echoes can be construed as constituting a psychological profile of the literary translator is a moot point; what does emerge clearly is a literary representation of a profession whose members are marginalised, transgressive, even fraudulent or impostors; at the very least, prey to identity instability.

\section{The status of the translator in translator-authored fiction}

Il faut bien dire qu'il n'est de traduction réussie que par une double trahison: celle de la langue prétendument maternelle du traducteur et celle de l'autre, prétendument étrangère.

D'où le déni général de ce travail, de ce non-travail, de cette jouissance d'agent double, perpétuellement en porte-à-faux entre deux cultures louchant l'une vers l'autre. (Durastanti 2002: 9-10)

Durastanti's comments open up anew the view of translation as treason or betrayal, the infamous traduttore, traditore, but with the important difference that she highlights here the complex positioning of the translator, "agent double", lurking between two cultures, two languages, "perpétuellement en porte-à-faux".

While there has been a certain amount of research on the role of the translator in the passage of meaning between languages, notably in the field of post-colonial translation studies, there has been little analysis of affective aspects of the literary translator. In fact, the ethical code of translation (and here we might think in particular of the ethics of interpretation, with its strict insistence on non-intervention and objectivity) is largely founded on a notion which marginalises the translator, turning him or her into a transparent entity, an "auteur de l'ombre" (Batista 2003: cover note), an essential participant whose existence is, paradoxically, denied.

Drawing principally but not exclusively on works of fiction about translators, chiefly of literature, written in English and French by translators, and working from the assumption that such literary texts may provide an 
opportunity for translator-authors to express precisely those affective elements which have no official place in the translation process, I propose to explore the representation of this fictional character as transgressive.

A shadowy figure whose very identity is destabilised by the work he or she does, the translator has also been described as an "apache de l'édition, voyou de la littérature" (Durastanti 2002: cover note). What is the origin of this negative image? What happens in fiction when the "apache" rebels and subverts the fundamental principles of the profession, as can be seen in Kosztolányi's short story "Le Traducteur cleptomane" (2002 [c.1933]), or Claude Bleton's Les Nègres du traducteur (2004), in which the translator's work precedes the writing of the original by the author? How do fictional translators relate to the other characters in the texts? Are they necessarily loners, or do they belong to particular social groups? How do they identify themselves and how are they seen by others? What is their relationship with the languages of their professional activities?

I am particularly interested in the issues of subjectivity and affect as they apply to literary translation, which, compared to the more technical end of the translation spectrum, tends to call on personal readings and personal decisions with greater frequency. That there is an individual approach to a literary work has long been recognised by reader-response theorists (e.g. Rabinowitz 1998), and it is not surprising that literary translation calls into play the same range of responses as reading does. While the literary translator does not create an original work in the same way as the original author, he or she does - and must - bring a great deal of personal creativity to the task. If someone writes a book or a poem and a second person translates it, the result is neither the original author's nor the translator's, but something in-between. However, this something in-between will almost universally be acknowledged as the author's, and the author's alone. To demonstrate the truth of this one need only go to the nearest bookshop or library, there to discover that Don Quixote, the Iliad and the latest of Fred Vargas' thrillers have as if magically emerged in more or less flowing English from the pens of the original authors - if the covers and title pages are anything to go by.

The literary translator must learn to cope with the kidnapping of his or her 'offspring'. There are also a number of other issues which may strike closer to home, undermining not just the value of the translators' work but also their self-image, even their identity. Some of these questions are explored in fiction by authors who are themselves translators, literary or otherwise.

\section{The loner and the outsider}

Barbara Wilson is an American writer of fiction, including mystery novels; she is also a translator of Norwegian literature. Her translator-sleuth, Cassandra Reilly, is a lesbian American with an Irish passport who earns a living translating from and into Romance languages. Reilly describes herself 
in Trouble in Transylvania as being good at "[r]eading train timetables, bargaining, writing postcards. Crossing borders. Transgressing boundaries. And of course translation" (Wilson 1993: 41). While Reilly has occasional romantic encounters, generally with other lesbian interpreters or translators, she is essentially a loner, clearly an outsider figure, not merely in the foreign cultures she visits but within her own, having grown up poor, Irish and Catholic in a predominantly WASP environment. Her second language, Spanish, was in fact an escape route for her, an opportunity to move beyond the limits imposed on her by this upbringing. Shifting identities is, significantly, a large part of the attraction of her chosen career as a translator.

Another writer, Briton Suzanne Glass who - according to the biographical note in her first novel, The Interpreter, speaks several languages and previously worked as a simultaneous interpreter - uses a heroine whose traits and profession resemble the author's. Dominique, who has a French mother whose parents were holocaust victims, and an English father, describes the way in which her job invades her life: "I often [hear] other people's words, other people's voices in my head for hours after I [come] out of the booth" (Glass 1999: 4). When doing consecutive interpreting, she describes herself as "a regurgitator par excellence" (18). Even the training for simultaneous translating is seen as being "to turn women and men in their mid to late twenties into translating machines. A programme where they [break] you down to build you up" (32). Of her career choice, Dominique says:

Words have demanded my concentration, my participation. They have exacted emotional response and intellectual involvement and I have given it willingly. [...] At times, they have sucked me dry and exhausted me. At others, they have excited and exalted me [...] But always I have paid a high price for that exaltation. (42)

Part of this high price is her relative isolation. All her close friends are social misfits - charming, but misfits nonetheless; one is a closet homosexual driven to despair by his need to masquerade for what he sees as his parents' benefit, and another is a flamboyantly foreign extrovert. Yet another character, this time an unlikeable although highly competent woman, is described in these terms, again with an emphasis on cost:

The price an interpreter pays to attain her level of skill is high. A woman like Marks is rootless. She belongs to every culture and then again to none. All her languages are her own, to play with and dominate as she wishes. And yet at her level no one language is truly her mother tongue. She, like many interpreters, is at home everywhere and nowhere. She is not at peace, never can be, for the words in her head can find no resting-place. (75)

Glass here associates highly-developed language skills with an intense sense of non-belonging; in fact it could be said of this particular character that multilingualism is equated with a distinct lack of social skills or any ability to be considerate of and open to others. We should note, too, the expression "like many interpreters" which generalises the condition. 


\section{The translator as shadow being}

Even greater dysfunctionality threatens and is again expressed as a general principle: "rooted to the task, the interpreter's imagination is starved. We cannot create. Only re-create. And eventually if we allow ourselves to be trapped in the world of second-hand words our imaginations shrivel and die" (Glass 1999: 77). Losing any sense of agency and personal direction, the interpreter positions herself literally inside the translation booth, figuratively in a kind of linguistic limbo, in a cocoon-like space and distanced from any active participation. When the tables are turned in the translation booth and Dominique must speak her own words she describes it as feeling "like cycling backwards" and "unsafe" (82). To stand on the sideline is clearly safer than to act on one's own behalf.

Science-fiction writers may take things further: in her Native Tongue trilogy (1985), Professor of Linguistics and sometime translator of native American languages (personal communication, August 2004), Suzette Haden Elgin creates a world in which the translators are the only social group able to interact with the aliens, important trading partners. As a result they are immensely wealthy and powerful, but they live in self-imposed protective isolation. Haden Elgin has turned the concept of genetically-based linguistic ability into a motive for isolating an entire group from the rest of society, which sees them as "linguist monsters" (Haden Elgin 1985: 174), possessed of incomprehensible language-learning abilities. Terran society is intensely misogynistic too, the women forced into submissive roles. The trilogy relates their campaign of stealth to put an end to this, but here again we see some of the negative or ambivalent traits described in the two previous works. "Her place was to interpret and translate, to respond as best she could to direct questions posed to her regarding the language and the culture of the aliens involved in the negotiations, and otherwise to be silent" (180). While we might well see this as perfectly ethical interpreter conduct, the context makes it clear these are negative behaviours, of women under male socio-economic domination.

Within this repressive framework, where women's roles are defined by laws which resemble but are even more restrictive than the Napoleonic code, language becomes a weapon of eventual liberation; the central female characters of Native Tongue literally become double agents, traitors and members of a Resistance movement made possible by the invention of a new, women-only language. In a sense, they are merely seizing control of the space to which they have been confined, but, although there is no real integration with the outside world at first, this is a radical and progressive turn of events.

\section{The self in flux - betrayal}

What we can see in each of these three quite different texts - a mystery, a romance, and a science-fiction novel - is a common theme of outsiderness, 
of the translator-interpreter as a person without the ability or opportunity to attach to the rest of society, a person who is at times deprived - by regulation or by professional habit - of the right to speak.

Translation studies scholar Michael Cronin, in Across the Lines (2000), a multi-faceted work on travel and translation, entitles one of his chapters about 'language-travellers', "The Changeling", again emphasising the misfit nature of the foreign language speaker. Here he explores some of the affective issues which confront those who manage to speak another language fluently and without a noticeable accent: "If the speaker of a foreign language is taken to be a native speaker of that language, after the initial feeling of self-congratulation, is there another sense of acting under false pretences, of pretending to be another and so losing one's identity?" (Cronin 2000: 48).

This raises the question of language skills as a form of impostor-hood. Yet it may be possible to see this "passing" as something more positive, "a space for the exploration of another self or of another element of self", as Cronin (2000: 53) puts it, here approximating the nomadic qualities proposed by Deleuze and Guattari (1976) as a form of resistance. Or, as Wilson's Cassandra Reilly says:

It is one of the remarkable aspects of language that we can appear to take on different personalities simply by making different sounds than the ones to which we are accustomed. [...] When I speak Spanish, the language I know best besides English, I find my facial muscles set in a different pattern, and new, yet familiar gestures taking over my hands. I find myself shrugging and tossing my head back, pulling down the corners of my mouth and lifting my eyebrows. I touch people all the time and don't mind that they stand so close to me and blow cigarette smoke into my face. I speak more rapidly and fluidly and I use expressions that for all my experience as a translator, I simply can't turn into exact equivalents. To speak another language is to lead a parallel life; the better you speak any language, the more fully you live in another culture. (Wilson 1993: 159-160)

This is a vivid description of what language-acquisition theorist Guiora (1972) has called "ego permeability", the ability to open oneself to the foreignness of another language at the level of one's personality. We must, I think, assume that this lack of fixed boundaries in the language learner, while beneficial for language skills, may also indicate a considerable degree of fluidity in self-image, something which may be a matter of course to the postmodern theorist but of more concern to the psychologist. We will return to this point later.

\section{The "no-win" translator}

So far we have essentially been considering oral rather than written translation; it is easy to see, for example, that the elements Wilson's heroine lists would more readily apply to situations in which the self is immediately and 
directly exposed and in which the production of (foreign) language is a physically visible process. But what of written translation, and more specifically, literary translation? In Who Translates? (2001) Douglas Robinson provides a thought-provoking exposé of what he terms, following Gregory Bateson, the translator's double bind.

It is as well to note here, even if only in passing, that Robinson's concept differs considerably from Bateson's original one, which referred exclusively to a schizogenic family situation. Here key factors come into play, such as repeated experience of conflict between family members, leading to a habituated response, and a qualitative difference between opposing injunctions, one of which must be less overt or concrete than the other. For Bateson, the debilitating power of the double bind resides in the fact that the victim's survival depends on his or her ability to resolve the insoluble and unacknowledged, because unspoken, conflict (Bateson 1972 [1956]: 206-212). Robinson's notion of the double bind, as he himself points out, modifies Bateson's concept considerably, notably in suggesting that the two conflicting imperatives are of "precisely the same level" (Robinson 2001: 175).

It is perhaps more appropriate then to refer instead to a "no-win situation" where Robinson's vision of the translator is concerned. He develops this notion over a number of pages in a complex chapter entitled "The Pandemonium Self", from which I cite the following example: to practise his or her craft appropriately the translator must "internalize the command to be both a neutral anonymous invisible channel (1) and a fully alive and creative artist (2) and expect censure for failure" (Robinson 2001: 175). In other words, he or she must be both a creative human being and a simple conduit. Despite the inherent contradiction of this statement many literary translators can indeed see the value of both functions: such an imperative - however we may label it - can only add to the stresses of the profession, a point developed extensively by Robinson.

\section{A touch of treason}

This is far from being the only difficult position in which the translator may find him or herself. Just as Cronin (2000: 47) points out in discussing the changeling nature of the translator, here citing Daniel Sibony, "[n]ot to betray one's origins (perfect accent) is to betray one's origins". Or to put a more literary frame on it, in the words of Sylvia Durastanti (2002: 9) cited earlier: "Il faut bien dire qu'il n'est de traduction réussie que par une double trahison: celle de la langue prétendument maternelle du traducteur et celle de l'autre, prétendument étrangère".

The translator's betrayal here is no longer the simple treachery of the old adage, but a complex and unavoidable impasse. The terminology Durastanti uses is revealing and - despite the partly positive title of her book of reflections on her career as a literary translator, Éloge de la trahison- 
clearly indicates the no-man's land inhabited by the translator, as a doubly double agent condemned to betray both languages precisely because of his or her linguistic competence.

And again, this time from Carlos Batista's Bréviaire du traducteur, “[d]e même que l'eau distillée se révèle insipide si elle n'est souillée par quelque élément étranger, ainsi, en traduction, la pure fidélité doit être panachée d'un zeste de trahison" (2003: 47). It is obvious that for Batista, as for Durastanti, there is a sense of illegitimacy associated with literary translation: distortion and treachery are nothing less than essential elements of the translation process.

Clearly, we are on the verge here of tipping over into the eternal debate of word vs sense, faithfulness vs naturalness, source text vs target audience - 'traduttore traditore', again. Our interest is not in discussing the pros and cons of very close translation but rather in looking at the translator's attitude when faced with these issues, or even simply with the translation exercise itself. How does he or she relate to the task at hand? Durastanti signals a lack of presence and a desire to rebel:

pour le traducteur il n'y a qu'une place possible: derrière la page. Impossible de se dire ça froidement, après avoir voué une vingtaine d'années à la traduction. L'effet d'étouffoir est garanti. Il est d'ailleurs immédiatement suivi de la violente envie de régurgiter ce bâillon de pâte à papier, cette boule compacte de caractères emmêlés, cette muselière palimpseste. Et il faut un bon moment avant de retrouver l'envie de retourner derrière la page, et d'y rester. (Durastanti 2002: 28)

It is worth underlining here the strong sense of physical discomfort - "violente envie de régurgiter" - brought on by this gagging: "étouffoir", "bâillon", "muselière" make this abundantly clear in their triple repetition. That these are all metaphors more logically associated with speech than with writing merely serves to reinforce the sense of physical invasion by the original text, in a way which relates closely to Glass's representation of the interpreter as physically invaded by another's words. Rebellion must be choked down for the disturbing work to proceed.

\section{Translation as counterfeit}

This "palimpsest muzzle", the constraint placed upon the translator by the need to reproduce (or write over) the original text, is problematic in another way. If indeed the translation is as good as the original, is it a counterfeit, a fraud? Or as Cronin (2003: 129) puts it: "Are students of literary translation training to be counterfeiters?" He goes on to add a brief mention of some famous cases of real fraudulent translations - Macpherson's $18^{\text {th }}$ century 'translations' of the poetry of the non-existent Ossian; J.C. Mangan's of the German poets 'Drechsler' and the suitably named 'Selber'. He also cites the case of Andreï Makine, a Russian writer in France whose French manu- 
scripts had been rejected and who resubmitted them as translations. The first was published in 1990. When the editor of the second, two years later, found the translation in need of checking by someone else, Makine had to translate his entire book into Russian, a task he apparently found rather difficult. Here the borderlines between true and false, original and imitation, are irretrievably blurred, and the question is posed - how might we judge the 'truth' of a literary translation?

In fiction it is possible to take this question of fraud even further, and this is precisely what Claude Bleton, a well-known French translator, has done in his novel Les Nègres du traducteur ('The Translator's Ghost Writers'). The main character is a former literary translator, Aaron Janvier, who recounts the story of his rise and fall. Beginning with a mere prettification of a book of statistics - to make it sell better - he moves on to sending synopses of novels to be written to the authors he then translates; eventually he translates the books before they are written, in a neat reversal of the creator-translator paradigm. But trouble strikes: "Juan Borrego Borrego [sic] en personne refusa tout net ma traduction d'un roman qu'il devait écrire et que je lui soumettais par politesse" (Bleton 2004: 75).

Faced with the author's continued bad behaviour, our hero has no option but to dispose of the recalcitrant writer and find another author for his translation. As he explains, leaving it to the translator-reader to understand the irony: "Il n'avait pourtant pas grand-chose à faire, il lui suffisait de suivre ligne par ligne ma traduction" (93). Behind this apparently disingenuous position lies another, more troubling one: the author is the primary driver of the original text - but is the translator not in fact the primary driver of his own creation, the translation?

More writers rebel and are eliminated. Running out of authors, Janvier tries to do the job himself: "j' essayai d'écrire tout seul. Un livre direct, sans traduction préalable. [...] Moi aussi, j'étais une sangsue. Aujourd'hui, je me dessèche, car je suis stérile, vieux parasite ayant vécu sur le croupion des auteurs" (122-123). Again we should note the strongly worded description: the translator is dried up, sterile, a parasite.

However ingenious he might seem - and Janvier surely pushes the boundaries here - the translator remains a secondary figure in the creative process. Obviously this is a humorous work poking fun at certain ideas of what a translator is and does. Yet the ultimate conclusion leaves him or her open to accusations of lack - as well as fraud.

One extraordinary text by a translator, and about a translator, also explores these ideas of lack and dishonesty, although in a different way. Originally written in Hungarian in the 1930s, Dezsö Kosztolànyi's "Le Traducteur cleptomane", tells us the story of a would-be translator who is fired when his editor discovers there's a great deal missing from his version of a bad English novel: the old castle's 36 windows have been reduced to 12, the 4 chandeliers have become 2,1500 pounds sterling is now 150 pounds ... and every last diamond of the countess' jewels has disappeared (Kosztolànyi 2002: 14-15)! 
On another level, we can see this text as an extended metaphor for the literary translator's (inevitable?) failure to put into the translation everything that is in the original. We can read Bleton's murderous translator story as a parable about the relationship between creator and translator - a parable in which the initially subservient translator becomes dominant but is finally forced to recognise his derivative nature. We can read the other fiction texts examined here as illustrations of the 'apartness' and the essentially solitary nature of the translator whose life revolves around other people's creativity, or who sees himself as a misfit, a crosser of boundaries, a transgressor.

Perhaps what we are really reading are the uncertainties and shortcomings of a career which is in many countries undervalued, and which places its practitioners in an uneasy space between creativity and imitation, between languages, between identities. If Robinson is right in describing the no-win position experienced by the literary translator, it is no wonder he or she is represented in fiction written by translators as a conflicted individual.

\section{A space for the translator - language and identity}

While perhaps not strictly fiction as we usually understand the term, Carlos Batista's parable-like texts provide much food for thought. While some are relatively positive and illustrate the many satisfactions of translation, there are plenty of examples of a more negative aspect, such as the following:

Une traductrice amoureuse de son auteur vint frapper à sa porte. Il demanda derrière la porte "Qui est là?" Elle répondit: “C'est moi!" Il dit "Il n’y a point de place pour toi et moi dans cette maison." Alors la traductrice s'en fut méditer dans des bibliothèques et des bars de nuit et, quelques mois plus tard, elle revint toquer à la porte de son auteur bien-aimé. Celui-ci questionna: "Qui est là?" La traductrice répondit: "C'est toi..." Alors seulement la porte s'entrouvrit. (Batista 2003: 13)

Here the translator must subjugate herself to the author, and to his work: in other words, must occupy no space. Much could be made of the assignation of genders in this example, along lines suggested by Michelle Coquillat in La Poétique du mâle (1982), which traces (19 ${ }^{\text {th }}$-century, notably Romantic) tropes of masculine creative superiority. Despite Bleton's humorous inversion of roles, the translator must necessarily follow the author, and it is all too easy to see this in terms of inferiority, a shadowy existence of imitation and support for 'real' creativity. Alongside this perceived secondary status is another factor to be considered, one to which I have already referred briefly in the context of Cronin's discussion: the question of the changeling, bilingual or multilingual person belonging nowhere.

Relatively little work exists which documents or analyses the literary translator's self-image or affective interface with his or her work. There are, on the other hand, a large number of studies of bilingualism and related iden- 
tity issues. These range from the very negative, claiming that to be bilingual is to be somehow unstable, "a marginal man", or even prone to schizophrenia (Adler 1977, qtd. in Grosjean 1982: 282), to the more sympathetic. Grosjean, for example, in his classic Life with Two Languages, reports that some quite normal bilinguals do feel a change in their personalities as they switch languages (1982: 278).

If, as Guiora (1982: 171) claims, "linguistic structures influenc[e] personality development and the emergence of stable personality parameters", and if the complementary argument that he advances is valid, that "confrontation with another language and its structures presents a challenge to native language and its psychological correlates, by offering alternative ways not only to describe but also to conceptualize, and perhaps to experience the world around us" (Guiora 1984: 4), then it is hardly surprising to find unsettled translator characters in translator-authored fiction.

While literary translators are not necessarily bilinguals in the sense that the term is used in many studies, they do constitute a highly specialised sub-group of people who straddle linguistic divides, moving between their languages in a particular mode of code-switching. This may have an impact on personality and self-image, as suggested above. However, more recent approaches to the question of identity have moved away from the concept of a fixed personality as a supposed norm.

The fluidity of the self-construct has become a given of postmodern studies where, as Pavlenko \& Blackledge (2004: 3) point out, we accept that we must "examine and explain negotiation of identities as situated within larger socioeconomic, sociohistoric and sociopolitical processes, and this in [...] context-sensitive ways". In this respect, works such as Eva Hoffman's significantly titled autobiography, Lost in Translation: A Life in a New Language (1989), can provide insights into the politics of identity, coupled with the need to adopt another language and its structures, which are relevant to the question of translator identity and self-image, and especially to the question of not belonging within a particular space.

While Hoffman's work gives consideration to many of the difficulties associated with cultural and linguistic duality, again within the field of bilingualism studies, Piller (2002: 270) reports more positively that contemporary theorists have begun to explore in depth affective aspects of language use and learning: "There is now some work beginning to emerge on second language learning as a form of 'language desire' [arguing that] language learning represents a desire to expand one's range of identities". Here we might think of Deleuze's and Guattari's (1976) concept of shifting, nomadic identities as affirmation and resistance, rather than as a dangerous instability. To "expand one's range of identities" is thus a positive act.

Certainly such a motivation can be seen in the example cited earlier from Wilson. Yet this openness is also accompanied in the majority of the literary works studied by a strong sense of marginality, exclusion, fraudulent behaviour or treachery. Perhaps as Cronin (2002: 55) has pointed out, citing Braidotti's work Nomadic Subjects (which for us must be reminiscent of 
Haden Elgin's Native Tongue), the translator may be seen as a monster, representing "the in-between, the mixed, the ambivalent" (Braidotti 1994: $77)$.

We may hypothesise that the negativities associated with fictional literary translators have their roots in several areas: the shifting identities associated with languages in interaction; the difficulties of literary translation as an inherently imperfectible task; and external factors such as the undervaluing of the translators' work. However until such time as we have access to more autobiographical and biographical accounts of literary translators which do explore affective aspects in depth, or to qualitative research in this area, we can only construct our hypotheses from fictional representations - recognising as we do so that they are only fiction, but looking closely at those elements which recur across several works and which in addition can be linked to existing research in related areas, such as bilingualism and second-language learning.

\section{Bibliography}

Adler, M. (1977). Collective and Individual Bilingualism. Hamburg: Helmut Buske Verlag.

Bateson, Gregory, et al. (1956). "Toward a Theory of Schizophrenia". Behavioral Science 1, 251-264. Reprinted in Gregory Bateson (1972). Steps to an Ecology of Mind. New York: Ballantine Books, 201-227.

Batista, Carlos (2003). Bréviaire d'un traducteur. Paris: Arléa.

Bleton, Claude (2004). Les Nègres du traducteur. Paris: Métailié.

Braidotti, Rosi (1994). Nomadic Subjects: Embodiment and Sexual Difference in Contemporary Feminist Theory. New York: Columbia UP.

Coquillat, Michelle (1982). La Poétique du mâle. Paris: Gallimard.

Cronin, Michael (2000). Across the Lines: Travel, Language, Translation. Cork: Cork UP.

Cronin, Michael (2002). "The Empire Talks Back: Orality, Heteronomy, and the Cultural Turn in Interpretation Studies". Maria Tymoczko \& Edwin Gentzler (eds). Translation and Power. Amherst/Boston: University of Massachusetts Press, 45-62.

Cronin, Michael (2003). Translation and Globalization. London/New York: Routledge.

Deleuze, Gilles \& Felix Guattari (1976). Rhizome. Paris: Minuit.

Durastanti, Sylvia (2002). Éloge de la trahison: notes du traducteur (essai). Paris/New York: Le Passage.

Glass, Suzanne (1999). The Interpreter. London: Arrow Books.

Grosjean, François (1982). Life with Two Languages. An Introduction to Bilingualism. Cambridge/London: Harvard UP.

Guiora, Alexander Z. (1982). "Language, Personality and Culture: or the Whorfian Hypothesis Revised". M. Hymes \& W. Rutherford (eds). On TESOL '81. Washington D.C.: TESOL, 169-177.

Guiora, Alexander Z. (1984). "The Dialectic of Language Acquisition". Language Learning 33(5), 3-12.

Guiora, Alexander Z., B. Beit-Hallahmi, R. C. L. Brannon, C. Y. Dull \& T. Scovel (1972). "The Effects of Experimentally Induced Change in Ego States on 
Pronunciation Ability in a Second Language: An Exploratory Study". Comprehensive Psychiatry 13(5), 421-428.

Haden Elgin, Suzette (1985). Native Tongue. London: The Women's Press SF.

Hoffman, Eva (1989). Lost in Translation: A Life in a New Language. New York: Penguin Books.

Kosztolànyi, Deszö (2002 [c. 1933]). Le Traducteur cleptomane et autres histoires (tr. Adàm Peter and Maurice Regnaut). Paris: Viviane Hamy.

Pavlenko, Aneta \& Adrian Blackledge (eds) (2004). Negotiation of Identities in Multilingual Contexts. Cleveland etc.: Multilingual Matters.

Piller, Ingrid (2002). Bilingual Couples Talk: The Discursive Construction of Hybridity. Amsterdam/Philadelphia: John Benjamins.

Rabinowitz, Peter J. (1998). Before Reading: Narrative Conventions and the Politics of Interpretation. Columbus: Ohio State UP.

Robinson, Douglas (2001). Who Translates? Translator Subjectivities Beyond Reason. Albany: SUNY Press.

Wilson, Barbara (1993). Trouble in Transylvania. Seattle: Seal Press. 